\title{
Corporate brand and hotel performance: A resource-based perspective
}

\begin{abstract}
Grounded in resource-based theory (RBT), our study analyzes the conditions that drive the effect of corporate brand on firm performance. Using a five-year panel of Spanish hotels, our results confirm that hotels with a corporate brand have greater profitability. In line with RBT, this effect is stronger when the corporate brand is more valuable to customers (e.g., in the lower-quality segment), when it is more difficult to imitate (e.g., older brands), and when it is exploited through specific organizational governance mechanisms (e.g., vertical integration). Contrary to RBT, we found a negative effect of the corporate brand as a rare resource on the performance of hotels that compete in the same city. More specifically, our results show that as the number of hotels using corporate brands increases, the profits of firms that compete nearby actually increase. Thus, the results provide general support for RBT, but also make an important qualification regarding the effect of resource rarity in industries where there may be agglomeration effects.
\end{abstract}

Keywords: corporate brand, profits, resource based theory, hotel industry 


\section{Corporate brand and hotel performance: A resource-based perspective}

\section{Introduction}

Companies can decide whether to use different brands across different products or a corporate umbrella brand that covers all of their products and services (Aaker, 2004). Compared to individual brands, corporate brands may provide a more solid basis for differentiating products and services because "although products or services tend to become similar over time, organizations are inevitably very different” (Aaker, 2004: 10). Moreover, the use of a corporate brand makes brand management less costly (Rao, Agarwal and Dahlhoff, 2004) and it ultimately has the potential to generate a sustainable competitive advantage (Balmer and Gray, 2003). However, we do not know yet under what conditions the corporate brand can have greater impact on financial performance.

Resource-based theory (RBT) provides a useful theoretical lens for explaining and predicting superior firm performance based on the analysis of the firm as a collection of resources (Barney, 1986, 1991; Peteraf, 1993). According to this perspective, a sustainable competitive advantage is generated only when resources are valuable, rare, and difficult to imitate or substitute, and the firm's organization allows for the proper exploitation of the resource (Barney, 1995). Although this theory has become central to the field of strategic management, the empirical testing of the theoretical predictions of RBT has been more challenging and the "systematic falsification remains very difficult" (Hoopes, Hadsen, and Walker, 2003: 889). Some scholars argue that RBT is tautological in its core and, thus, not subject to empirical test (Priem and Butler, 2001), mainly 
because of problems to parameterize the concepts of value, rarity, and inimitability (Hoopes et al., 2003; Kraaijenbrink, Spender, and Groen, 2010; Priem and Butler, 2001). In this paper, we present an empirical study of the corporate brand as a strategic resource that overcomes the problems of parameterizing the RBT and the four key elements of the Value-Rarity-Inimitability-Organization (VRIO) framework (Barney, 1995). More specifically, we analyze the circumstances under which the use of a corporate brand may have a greater impact on firm profits, arguably when a corporate brand provides greater value, it is rarer and more difficult to build, and it is exploited through proper organizational arrangements.

To address this research question, we use a unique dataset of Spanish hotels. Spain was the third most visited country in the world in 2016 (UNWTO, 2016) with a highly competitive hotel industry ${ }^{1}$, represented both by domestic and global players. Critical in our study, we can distinguish between hotels within a specific company that use the corporate brand name (e.g., NH Hotels) and those that do not, which are typically smaller chains or independent hotels that use individual brand names for each hotel. This distinction allows us to measure the effect of a corporate brand on the financial performance of each individual hotel, regardless of whether they are independent hotels or part of chain, using or not a corporate brand within the hotel chain. We believe that using the hotel industry in our study of corporate brands is especially appropriate because, unlike most extant research, we can identify, isolate, and measure all four features of strategic resources in the VRIO framework.

\footnotetext{
${ }^{1}$ Spain ranked first among 141 countries in the Travel and Tourism Competitiveness Index of the World Economic Forum, 2015.
} 
Our empirical results confirm that a corporate brand is indeed a strategic resource that helps individual hotels to obtain higher profits per room. We provide strong evidence that the effect on profits increases when the hotel competes in the low-quality segment, the corporate brand is older, or the hotel is vertically integrated. However, we find opposite results to RBT regarding the rarity of using a corporate brand. Contrary to our initial expectations, we find that when hotels with a corporate brand agglomerate in one location close to each other, the profits of those hotels actually increase, despite controlling for differences in location attractiveness. We interpret this finding to be in line with prior research on the agglomeration literature in the hotel industry.

Our study makes two key contributions to the literature on strategic resources and firm performance. First, our results provide clear evidence that the corporate brand is indeed a strategic resource that may improve the performance of hotels. We find that hotels with a corporate brand generally enjoy greater profits per room, but not all of them benefit equally from the use of a corporate brand. RBT serves to identify three critical moderators of the performance implications of the corporate brand for hotels, specifically regarding its value, inimitability, and organizational alignment. Second, our results indicate that hotels with a corporate brand actually benefit from the presence of nearby hotels that also use corporate brands. This result is consistent with previous work on agglomeration benefits in the hotel industry, though it is contrary to our initial expectations about resource rarity from a resource-based view. Thus, our study contributes to clarify the boundary conditions for applicability of RBT and one of its core ideas regarding scarce resources to industries that may be affected by agglomeration effects, such as the hotel industry. 


\section{Theory and hypotheses}

\subsection{Corporate brand and firm performance in the hotel industry}

There is some empirical evidence of a positive relationship between the use of corporate brands and firm performance (Fetscherin and Usunier, 2012). For instance, Rao, Agarwal, and Dahlhoff (2004) found that firms that use corporate brands have higher intangible value (i.e., higher values of Tobin's q) compared to firms that use a house of brands (i.e., distinct brands that are not linked to the corporate brand). Similarly, Wang and Sengupta (2016) found a positive relationship between corporate brand equity (measured as the ratio between the value of the corporate brand and total assets) and corporation value (i.e., Tobin's q).

There are several reasons for the positive performance consequences of corporate branding. The use of the corporate brand (e.g., NH hotels) can decrease marketing costs through economies of scale (Rao et al. 2004). It also reduces consumer search costs and provides a signal of product quality and consistency, which can be valuable to customers, especially when buying products whose quality can only be assessed after the purchase (e.g., experience goods) (Kirmani and Rao, 2000; Weigelt and Camerer, 1988; Wernerfelt, 1988). Moreover, corporate brands help firms to differentiate themselves in the minds of their stakeholders (Balmer and Gray, 2003). However, it may be difficult to separate the corporate brand effect from the performance consequences of a broader corporate-level effect (Rumelt, 1991). The hotel industry provides an excellent context to investigate the performance implications of the corporate brand because of the presence of both individual hotels and hotel chains, which use a corporate brand in some of their individual hotels, but not always across all of them. 
Within the hospitality industry, there is some evidence of the superior performance of hotels that use a shared brand name (O'Neill and Carlbäck, 2011; O'Neill and Mattila, 2006), although these studies do not specifically examine the relationship between corporate brand and financial performance. Hotel chains may benefit from economies of scale in marketing and greater efficiency in creating brand equity to be shared among its individual hotels (Rao et al. 2004), both of which can decrease marketing costs. It also allows hotels to exploit the homogeneity of services offered to consumers, which makes its brand a signal of hotel quality (Ingram, 1996; Wernerfelt, 1988). The use of a corporate brand can serve as a guarantee of hotel quality to the extent that its shared reputation would be damaged if even one hotel offers poor quality service. Given the lower marketing costs and the possibility of creating a differentiation advantage for hotels that use a corporate brand, we can formulate our baseline hypothesis:

H1. There is a positive relationship between the use of the corporate brand and an individual hotel profitability.

\subsection{The value of a corporate brand for hotels}

In the rest of this section, we analyze under what conditions we should expect that the use of corporate brand might have greater positive impact on hotel profitability. To do so, we build on RBT, which explores the features for a particular resource to generate superior performance, as captured in the VRIO framework (Barney, 1991; Barney, 1995). Unfortunately, the conceptualization of resource value as the fundamental feature of strategic resources has been problematic because it may be defined in terms to the 
capacity of a resource to increase firm performance in the first place (Priem and Butler, 2001). To overcome this tautological definition, researchers have begun to identify the conditions under which different resources can be more or less valuable (Schmidt and Keil, 2013).

In the context of the hotel industry, we argue that the corporate brand will be less valuable when the hotel already possesses other resources that also signal high quality, particularly, the number of stars, as a critical gauge of a hotel's quality. Prior literature has shown that the effectiveness of corporate brand as a quality signal will be reduced when there are other signals that provide information about quality (Biong and Silkoset, 2014). Thus, we should expect a substitution effect among different signals of quality, such that the signal's relevance will decrease when it is used with another signal that provides similar information about unobservable quality (Basuroy, Desai and Talukdar, 2006).

In the context of the hotel industry, the potential value that a corporate brand can bring to a particular hotel depends on the particular features of the hotel and the extent to which adding a corporate brand can have a substantial impact on consumer perceptions of hotel quality. Hotels that compete in the high-quality segment (i.e., five-star hotels) already offer their guests an enhanced bundle of services through tangible elements such as more facilities, greater service variety, and larger rooms. Hotels with more stars are guaranteed to provide higher quality to its customers, but this inherent higher quality also limits the relative benefit that a corporate brand can bring to the hotel. Conversely, the corporate brand may provide relatively greater value to hotels that compete in the lowquality segment (i.e., hotels with fewer stars) because these hotels are more limited as a 
collection of resources, so that the addition of a new resource (i.e., a corporate brand) can potentially have a greater impact on hotel performance. Thus, from a resource-based perspective, a corporate brand should be less valuable as a guarantee of quality for customers for the higher-quality segment.

H2. The positive effect of a corporate brand on hotel profitability is greater for hotels competing in the low-quality segment than for hotels with greater number of stars.

\subsection{The corporate brand as a rare resource for hotels}

According to RBT, having a valuable resource is insufficient to generate a competitive advantage if other firms also hold this resource. Thus, a resource must also be rare, that is, controlled by a small number of competitors (Barney, 1991). If a resource is valuable but common and widely available, it can only be a source of competitive parity, whereas if it is valuable and rare, it has the potential to create a competitive advantage.

This generic idea about the need for strategic resources to be rare can also be applied to corporate brands in the hotel industry. Arguably, a corporate brand should have greater impact on the hotel's performance, when any other hotel uses a corporate brand in a given location; in other words, if having a corporate brand is relatively rare among the hotels in the area. In contrast, if there are no limits to competition (Peteraf, 1993) and many hotels have access to a corporate brand, its use can hardly provide any advantage. Thus, based on RBT, we can expect that the greater the percentage of hotels that use a corporate brand in a given geographical area, the smaller the potential positive impact of the corporate brand on the hotel's profitability. 
It should be noted that to properly capture the hypothesized greater effect of corporate brand on hotel profits when having a corporate brand is indeed rare, we would have to remove other locational factors that could have an impact on hotel performance, which are critical in this industry. It is widely acknowledged that better locations should be associated with greater profits, which in turn may attract more competitors to the same geographical area (Kalnins and Chung, 2004). Thus, we need to use multilevel techniques to account for the nesting of hotels within cities with different levels of attractiveness (and hence profitability), as well as firm-level features, e.g., central location within the city. Once we have accounted for differences across cities and hotel features, we can formulate the following hypothesis based on RBT:

H3. The positive effect of a corporate brand on hotel profitability is greater when most of a firm's competitors do not use a corporate brand than when a high percentage of its competitors also use a corporate brand.

\subsection{Imperfect imitability of a hotel corporate brand}

A resource is imperfectly imitable when the competitor's cost to develop or obtain it is extremely high (Barney, 1995). Corporate brands are difficult to imitate for a number of reasons. In the strictest sense, the brand name and logo are legally protected and thus each brand name is unique by law and cannot be precisely replicated by competitors (Balmer and Gray, 2003). Building a strong corporate brand implies the alignment of strategic vision, organizational culture, and corporate image, which is a complex, timeconsuming process that reduces brand imitability (Hatch and Schultz, 2003). It is well established that brands cannot be obtained with money alone (Kozlenkova, Samaha and 
Palmatier, 2014), because brand building is a socially complex and causally ambiguous task (Hooley, Greenley, Fahy and Cadogan, 2001), which is the result of a unique historical pattern of development (Balmer and Gray, 2003). Thus, replicating a corporate brand is a difficult challenge that severely limits the imitability and substitutability of a successful brand.

Most independent hotels throughout Europe are generally too small, often poorly located, to be accepted as a franchisee of an existing hotel chain (Holverson and Revaz, 2006). Thus, it is difficult for independent hotels to join existing chains, especially chains with the most firmly established hotel brands. It is even more difficult for an independent hotel to build a branded chain on its own. Having a successful brand requires integrated revenue maximization strategies and techniques and proper employee training to achieve consistency in service delivery (Forgacs, 2003).

From a resource perspective, developing and maintaining a successful corporate brand is a costly and challenging undertaking that requires substantial financial resources, sophisticated expertise, and a long-term horizon to create the uniqueness of the brand in the mind of the customer. Competitors "cannot easily match lasting impressions left in the minds of individuals and organizations by years of marketing activity" (Kotler, Keller, Brady, Goodman and Hansen, 2009: 429). In this sense, older corporate brands should be more difficult to obtain (via franchising) or replicate (via imitation). Hence, to the extent that older corporate brands should be more difficult to imitate or substitute, they should have a greater impact on hotel profitability. In other words:

H4. The positive effect of corporate brand on hotel profitability is greater for old brands than for new brands. 


\subsection{Organizational exploitation of a corporate brand}

RBT also claims that having an appropriate organizational form to exploit the potential of the resource is the final critical condition that allows a firm to generate a sustainable competitive advantage from a strategic resource (Barney, 1995). The possession of a valuable, rare, and inimitable resource may not be sufficient to fully leverage its potential to contribute to superior performance without appropriate organizational structures, processes, and policies. In this case, the organization acts as an "adjustment factor" that either enables or prevents a firm from fully realizing the benefits embodied in its valuable, rare, and costly-to-imitate resource (Kozlenkova et. al., 2014).

In the hotel industry, real estate ownership can be separated from hotel management, which leads to different governance structures (de Roos, 2010). A hotel chain can be vertically integrated by owning and operating its hotels, in which case the chain controls the building property, hotel brand, and hotel management. This organizational form allows maximum control and coordination of the assets of all hotels in the chain. As an alternative, hotel chains can be responsible for strategy and management of daily operations, but they may rent the building from a real estate company. Hybrid organizational governance structures, such a franchising, are also possible (Kosová, Lafontaine, and Perrigot, 2013), though they are virtually non-existent in the Spanish hotel industry.

Based on transaction cost economics (Williamson, 1985), previous research has shown that firms choose to vertically integrate when the relationship involves specific investments (e.g., Minkler and Park, 1994). When a firm makes a relation-specific 
investment, the more specific the investment is, the lower its value in alternative uses. In such a case, the firm may under-invest because it foresees the potential for the other part to engage in self-interested behavior in the future. Through vertical integration, firms minimize this risk of underinvestment, which contributes to increase performance in situations with high asset specificity (Williamson, 1985; Miller, 2011).

We argue that the relationship between property owners and hotel management companies generally requires investments in brand-specific assets, e.g., specific design of the building or its decoration. As property owners can foresee the potential opportunistic behavior of hotel companies, they may underinvest in those elements more specific to the brand if they set an arm-length relationship. In contrast, we expect that hotels owned and managed by the same company do not have a disincentive to make brand-specific investments, because they should be able to extract the full value of any investment in the corporate brand. Thus, we expect that a corporate brand will have greater impact on hotel performance when the hotel the hotel is owned and managed by the same company: H5. The positive effect of corporate brand on hotel profitability is higher when the hotel is owned and managed by the same company (i.e., vertically integrated) than when the hotel is owned and managed by different companies (i.e., not vertically integrated).

\section{Data and Method}

\subsection{Data}

We used a variety of secondary data sources (e.g., Official Hotel Guide, Spanish Patent and Trademarks Office, Hotel Occupancy Survey, etc.) to build a comprehensive dataset of hotels in Spain for the five-year period covering 2004-2008, before the industry 
was severely impacted by the recent global financial crisis. The entire population of hotels in Spain comprises 43,172 hotel-year observations spanning five years. We collected data from the SABI database (Sistema de Análisis de Balances Ibéricos) on the profits of individual hotels. First, we used the 2005 Census of Hotels from Alimarket to obtain the name of the company that operates each hotel. Second, we collected the financial data of each company from the SABI database, discarding all companies that were diversified into other activities. Because public information about individual hotel performance is available for a relatively small number of hotels, our final dataset was limited to 1,509 hotel-year observations, which was further reduced to a final sample of 998 hotel-year observations after hotels with missing data were discarded.

\subsection{Variables description}

\subsubsection{Dependent variables}

Yearly Gross Profit per Room is the key dependent variable in our analysis and is derived using data reported in the SABI database. To calculate this variable, we divided the yearly total gross operating profit by the number of hotel rooms. The gross operating profit per available room is one of the most commonly used profitability measures in the hospitality industry (Singh and Dev, 2015).

\subsubsection{Independent variables}

We use the variable Corporate Brand as our key independent variable. This dummy variable was manually coded and takes the value of one when the hotel brand 
includes the parent group name, such as Meliá, NH, or Barceló, and the value of zero when the hotel brand name does not include the corporate brand name.

To measure value, we use the Number of Stars (from one to five) of each hotel as reported in the Official Hotel Guide (published yearly by Instituto de Estudios Turísticos). This variable indicates the market segment in which each hotel competes (i.e., luxury vs. economy).

To measure rarity, we use the variable Percentage of Non-Branded Hotels, which measures the ratio of competitors in the municipality that do not use a corporate brand over the total number of competitors located in the municipality.

To measure the inimitability of the corporate brand, we use Brand Age. The age of corporate brands is computed as the number of years since the corporate brand was registered in the Spanish Patent and Trademark Office, while we used the number of years since the hotel opened for individual hotels that do not have a corporate brand. For the latter hotels, we collected data for the year in which the hotel received a license to open from the tourism department of each autonomous region in Spain.

Finally, to measure organizational differences to exploit the corporate brand, we use the dummy variable Vertical Integration, which takes the value of one when the hotel is owned and managed by the same company and the value of zero otherwise. We obtained the names of the owners and management companies from the Alimarket Census of Hotels.

\subsubsection{Control variables}


We included several control variables in the analysis to account for key attributes of the hotel. All of these variables were obtained from the Official Hotel Guide.

Chain is a dummy variable that captures whether the hotel is part of a chain, regardless of whether the hotel uses the corporate brand or not. By including this variable in the analysis, we guarantee that the benefits of a corporate brand are not confounded with other benefits that a hotel may receive for its affiliation with a chain as part of a broader corporate effect (Rumelt, 1991).

To control for hotel services that may influence hotel profits because they can affect both customer willingness to pay and hotel costs, we use the following dummy variables: Historical Building, Parking, 24-Hour Room Service, Meeting Rooms, Family Rooms and Accessible Facilities for the Disabled. The number of Leisure Services represents the sum of all leisure services offered by the hotel (e.g., nightclubs, swimming pools, tennis, golf, etc.).

Central Location is a dummy variable that captures the attractiveness of the hotel's location within the city. It takes the value of one if the hotel is located at the center of the city and the value of zero otherwise, which is a key feature for large number of customers.

Uniqueness controls for the extent of hotel differentiation. This variable was built as the average percentage of hotels that do not offer each service. The range of this variable is from 0 to 1 , with a level close to 1 implying that the service provided by the hotel is not provided by any other hotel in the same city, which indicates that the hotel is unique in terms of service and thus will face a lesser degree of price competition.

We also control for key differences across cities: 
Occupancy Rate controls for the strength of demand between cities. It was collected from the Hotel Occupancy Survey published by the National Statistics Institute and is calculated as the ratio between the average number of occupied rooms per month and the total number of rooms available.

Unemployment Rate controls for differences in personnel costs between cities. Data for this variable were collected from the Economic Year Book published by la Caixa, which provides economic data at the municipal level. The unemployment rate is calculated as the number of unemployed people in the city over the potential labor force (i.e., the population between 15 and 64 years old).

\subsection{Empirical analysis}

The data are organized at the hotel level and thus there are 998 hotels nested within 77 locations (i.e., cities) across five years. To account for differences across locations, we use a multilevel regression model with city random-effects (XTMIXED in Stata). We also control for unobserved effects associated with changes in profitability across time through Year Dummies (year fixed effects). To check the robustness of our results, we replicated the entire analysis using traditional OLS regression with location fixed-effects, which provided the same conclusions as those reported in the next section.

\section{Results}

Tables 1 and 2 display the descriptive statistics and correlations for the main variables in our study. 
Tables 1 and 2 about here

Table 3 shows the regression analysis of Yearly Gross Profit per Room. The intraclass correlation coefficient is 0.2737 , meaning that $27.37 \%$ of the variance is attributable to the city-level, and the remaining $72.63 \%$ is attributable to differences between individual hotels. We assessed the fit of the model by examining the deviance statistics and found that the full model (deviance equal to -19,667.18) was a significantly better fit than the model including the controls (deviance equal to $-19,739.16 ; \chi^{2}[5]=71.98, p<$ $.001)$.

Table 3 about here

In model 1, we included only the control variables. In model 2, we added the variable Corporate Brand to test Hypothesis 1. Consistent with this hypothesis, we found that the coefficient was positive and significant $(\beta=4,598.39, \mathrm{p}<0.01)$, suggesting that the annual per room profits of hotels with a corporate brand are $€ 4,598.39$ greater than those of hotels that do not use a corporate brand. It is interesting to note that the positive performance impact of being part of chain in Model 1 disappears in Model 2, once we specifically account for the effect of sharing a corporate brand, which is a critical contribution from the chain to each of its individual hotels.

In model 3, we included the interaction of Corporate Brand with the four features of corporate brand as a strategic resource that were hypothesized to moderate its effect on performance. Regarding brand value, we found a negative and significant coefficient on the interaction between Corporate Brand and number of Stars $(\beta=-6,838.55, p<0.01)$, 
suggesting that corporate brand indeed has value for hotels that compete in the lowquality segment, supporting Hypothesis 2.

The same model shows no significant moderation effect of Percentage of NonBranded Hotels in the City on the interaction between corporate brand and performance; therefore, Hypothesis 3 is not supported. This hypothesis predicted that rarity (i.e., a higher percentage of non-branded hotels) strengthened the effect of corporate brand on performance. However, the main effect of the Percentage of Non-Branded Hotels in the City shown in model 2 is negative and significant $(\beta=-3,958.71, p<0.05)$, which suggests that the presence of many non-branded hotels decreases the profitability for all hotels across the cities in our sample.

We also found a positive and significant coefficient on the interaction between Corporate Brand and Brand Age $(\beta=768.97, \mathrm{p}<0.05)$, suggesting that the effect of corporate brand on profitability is stronger when the corporate brand is older and therefore more difficult to imitate, which supports Hypothesis 4.

Finally, the coefficient on the interaction between Corporate Brand and Vertical Integration was positive and significant $(\beta=15,526.77, \mathrm{p}<0.01)$, confirming that hotels owned and managed by the same company are able to obtain higher profitability from the use of a corporate brand, as suggested by Hypothesis 5 .

\subsection{Additional analyses about agglomeration in the hotel industry}

We performed additional analyses to better understand the unexpected findings regarding the lack of significance for Hypothesis 3 regarding the rarity of corporate brands, which is a key feature of strategic resources from RBT. We explored an 
alternative explanation based on the presumed benefits of hotel agglomeration. Prior research has shown that hotels with higher quality mutually benefit when other high quality hotels locate near them (Canina, Enz and Harrison, 2005), sharing common infrastructure and strengthening the attractiveness of the area for customers. To explore a possible agglomeration effect of corporate brands, we computed two additional variables dealing with the number of hotels using a corporate brand rather than the percentage, one at the city-level and another within a two-kilometer radius of each hotel. For this narrower measure of hotel agglomeration, we first obtained data on the precise latitude and longitude of each hotel based on its physical address and, then, we used the Stata command geonear to calculate the number of hotels within a two-kilometer radius.

Table 4 shows the results of this multilevel regression analysis. We included as an independent variable the total number of hotels in the city that use corporate brands and another specification with hotels within a two-kilometer radius. Model 1 shows a positive and significant effect of the number of hotels that use corporate brands $(\beta=70.35$, $\mathrm{p}<0.01$ ) on hotel performance, which suggests that all hotels benefit from the presence of more hotels with corporate brands. Model 2 shows a positive significant interaction of this new variable with the use corporate brand $(\beta=98.81, \mathrm{p}<0.01)$, such that the corporate brand effect is greater when there are more hotels that also use a corporate brand in the same city. Using a narrower definition of agglomeration, Model 3 shows a positive significant coefficient for the number of hotels with corporate brands within a twokilometer radius $(\beta=97.34, p<0.01$ ), and Model 4 confirms a positive significant interaction effect provides a significant interaction with with corporate brand $(\beta=301.35$, $\mathrm{p}<0.01)$ 
Table 4 about here

Two reasons may explain these results, which are contrary to the presumed benefits of having rare resources from RBT. The first possible explanation is based on pure location benefits. Branded hotels are attracted to particular areas because of the unique features of these areas (for example, hotels co-locate along beaches or near key tourist attractions, where demand is concentrated). In this case, the source of higher profitability should be attributed to the attractiveness of the location, but not to the greater number of hotels in the area. Thus, our measure of rarity based on the number of hotels could still be picking up differences in location attractiveness, despite controlling for differences across cities in our multilevel analysis as well as for central location within a city.

A second explanation relies on agglomeration theory, which predicts that firms receive benefits when more firms co-locate in the same area, triggering positive spillover effects. Several studies based on agglomeration theory have shown that higher numbers of firms with superior quality may increase the performance levels of all neighboring firms, allowing them to increase their prices (Canina et al., 2005; Chung and Kalnins, 2001). For instance, Chung and Kalnins (2001) show that hotels located in rural markets obtain higher revenues per room when they are surrounded by a higher percentage of chain-affiliated hotels. Canina et al. (2005) found evidence of "differentiation spillovers" in the hotel industry, which exist when firms benefit from the investments of differentiated competitors that make a location more attractive.

We performed further analysis to investigate which of these rationales may be driving our results, i.e., superior location versus agglomeration benefits (McCann and 
Folta, 2008). To do so, we separately included in the same regression the number of branded hotels and the number of non-branded hotels. If a greater number of hotels are attracted to a specific geographic area because of its unique inherent conditions, all hotels in the given location will be associated with higher profits, regardless of whether they have a corporate brand; in other words, all hotels should benefit from being in a more attractive location, so that location factors drive superior performance. However, if the higher profits are due exclusively to the positive spillover effects of branded hotels, we should observe a positive coefficient only in the profit regression for the number of branded hotels, but not for the number of non-branded hotels, so that agglomeration of branded hotels drive superior performance.

Table 5 shows the results of this analysis with the number of both branded and non-branded hotels. Model 1 shows a positive and significant effect of the number of hotels that use corporate brands $(\beta=90.69, \mathrm{p}<0.01)$ on hotel performance, whereas the effect of the number of hotels that do not use corporate brands on hotel performance is negative, but only marginally significant $(\beta=-15.93, \mathrm{p}<0.1)$. These results suggest that hotels benefit from the presence of more hotels with corporate brands, but they do not benefit from the presence of hotels without corporate brands, which may actually hurt profitability. Model 2 shows no significant moderation between corporate brand and the number of hotels with and without corporate brands, so that the entire city may be too large to detect any agglomeration effects. Using the narrower definition of agglomeration, Model 3 also shows a positive and significant effect of the number of hotels with corporate brands located within a two-kilometer radius $(\beta=93.87, \mathrm{p}<0.01)$, whereas the effect of the number of hotels without corporate brands within a two-kilometer radius is 
not significant. Most critically, Model 4 suggests a positive and significant interaction effect of the number of proximate hotels that use corporate brands on the impact of corporate brand on performance $(\beta=914.76, p<0.01)$, whereas the effect of the number of proximate hotels without corporate brands is negative and marginally significant ( $\beta=-$ $230.56, \mathrm{p}<0.1)$.

In conclusion, these results support the agglomeration benefits of co-location with hotels that use corporate brands, though we need a narrow definition of agglomeration (i.e., co-location within two kilometers) and not for the entire city, which only provides marginally significant results.

\section{Table 5 about here}

\section{Discussion}

Our study provides strong evidence that the corporate brand is a strategic resource associated with superior firm performance in the hotel industry (Balmer and Gray, 2003). We further analyze how the required attributes of strategic resources according to a resource-based view can be used to understand when hotels using a corporate brand may be expected to experience greater profitability. Our findings confirm that the use of a corporate brand has a greater impact on hotel profits per room when the corporate brand is more valuable to customers (i.e., in the lower-quality segment), when it is more difficult to imitate (i.e., older), and when it is exploited through proper organizational governance mechanisms (i.e., vertical integration). 
Although we generally find support for RBT in our analysis of corporate brands, our results also provide novel insights into the performance consequences of hotel brands based on their rarity. Though RBT researchers suggest that a resource must be controlled by a small number of firms to be a source of competitive advantage, we found either insignificant, or even the opposite, results for the percentage of non-branded competitors. When we explored an alternative variable based on the number of hotels in the city with corporate brands and within a two-kilometer radius, we found that hotels that use corporate brands actually benefit from the presence of other hotels with corporate brands.

The agglomeration literature helps to explain this result. Certain firms possess resources that can contribute to increases in demand, which can benefit nearby firms when spillovers can occur. Brand affiliation is one of those resources. Because brands signal higher unobserved quality (e.g., area safety), branded hotels can reduce consumer search costs and thus attract customers to the area. Once in the area, customers can compare and find other hotels that better fit their preferences. This explanation is consistent with previous work on agglomeration effects (Canina et al., 2005; Chung and Kalnins, 2001).

Our results contribute to this stream of literature by showing that there is a clear agglomeration effect for corporate brands, which increases the profits for firms competing nearby. Many corporate brands, each with their own differentiation, can coexist without the negative effects usually associated with greater competition for strategic resources.

In sum, our study suggests that key ideas about resource scarcity in RBT need to be reconsidered, at least in industries where there may be agglomeration benefits, such as 
the hotel industry. We have shown that as the number of proximate competitors owning these resources increases, the earning potential of these resources can also increase. Our findings regarding rare resources in the context of corporate brands constitute an important qualification to standard RBT, and future researchers may wish to investigate other types of resources that may be subject to this qualification in addition to the corporate brand.

\subsection{Managerial implications and limitations}

The findings of this study have practical implications for brand strategy. The empirical evidence provides clear recommendations to hotel managers regarding the conditions under which they may want to develop the corporate brand (e.g., lower-quality hotels, older brands, vertically integrated companies, and the presence of more hotels using corporate brands). These findings also provide guidance to corporate managers about the circumstances conducive to creating and exploiting their brands, especially the superiority of vertical integration for hotel management.

There are several limitations in our study that we should briefly highlight. First, the generalization of our conclusions to other industry contexts should be done with caution due to the nature of our sample. The hotel industry provides an excellent setting for investigating the effect of a corporate brand on local performance, but the use of this setting may reduce the applicability of our results to other industries, especially industries that do not offer experience goods and in which competition is not localized. Second, very few hotels changed their corporate brand during the five-year period under investigation, precluding the analysis of hotel performance before and after this decision. 
Thus, our analysis is essentially based on between-unit effects and we cannot assess whether performance issues motivated the initial decision to use a corporate brand. Lastly, our sample dates back to 2004-2008, which may raise concerns regarding the age of our data. However, we believe that our focus on the effect of corporate brand on firm performance and our theoretical framework still remains relevant today. Moreover, the inclusion of data after 2009, when a severe financial crisis hit Spain, might have significantly biased our analysis, since the hotel industry was significantly affected by the economic downturn. Despite these concerns, we believe that our findings make a valuable contribution to research on the relationship between strategic resources and performance. 


\section{References}

Aaker, D.A. (2004). Leveraging the Corporate Brand. California Management Review, 46(3), 6-18.

Balmer, J.M.T., \& Gray, E.R. (2003). Corporate brands: what are they? What of them? European Journal of Marketing, 37(7/8), 972-997.

Barney, J. B. (1986). Organizational culture: Can it be a source of sustained competitive advantage? Academy of Management Review, 11(3), 656-665.

Barney, J.B. (1991). Firm resources and sustained competitive advantage. Journal of Management, 17(1), 99-120.

Barney, J. B. (1995). Looking inside for competitive advantage. Academy of Management Executive, 9(4), 49-61.

Basuroy, S., Desai, K. K., \& Talukdar, D. (2006). An empirical investigation of signaling in the motion picture industry. Journal of Marketing Research, 43(2), 287-295.

Biong, H., \& Silkoset, R. (2014). The ineffectiveness of corporate brand investments in creating price premiums. Journal of Marketing Theory \& Practice, 22(2), $169-184$.

Canina, L., Enz, C.A., \& Harrison, J.S. (2005). Agglomeration effects and strategic orientations: Evidence from the US lodging industry. Academy of Management Journal, 48(4), 565-581.

Chung, W., \& Kalnins, A. (2001). Agglomeration effects and performance: A test of the Texas lodging industry. Strategic Management Journal, 22(10), 969-988.

de Roos, J.A. (2010). Hotel Management Contracts--Past and Present. Cornell Hospitality Quarterly, 51(1), 68-80. 
Fetscherin, M., \& Usunier, J. (2012). Corporate branding: an interdisciplinary literature review. European Journal of Marketing, 46(5), 733-753.

Forgacs, G. (2003). Brand asset equilibrium in hotel management. International Journal of Contemporary Hospitality Management, 15(6), 340-342.

Hatch, M.J., \& Schultz, M. (2003). Bringing the corporation into corporate branding. European Journal of Marketing, 37(7/8), 1041-1064.

Holverson, S., \& Revaz, F. (2006). Perceptions of European independent hoteliers: hard and soft branding choices. International Journal of Contemporary Hospitality, 18(5), 398-413.

Hooley, G., Greenley, G., Fahy, J., \& Cadogan, J. (2001). Market-focused resources, competitive positioning and firm performance. Journal of Marketing Management, 17(5/6), 503-520.

Hoopes, D. G., Hadsen, T. L., \& Walker, G. (2003). Guest editors' introduction to the special issue: Why is there a Resource-Based view? Toward a theory of competitive heterogeneity. Strategic Management Journal, 24(10), 889-902.

Ingram, P. (1996). Organizational form as a solution to the problem of credible commitment: The evolution of naming strategies among U.S. hotel chains, 1896-1980. Strategic Management Journal, 17(1), 85-98.

Kalnins, A., \& Chung, W. (2004). Resource-seeking agglomeration: A study of market entry in the lodging industry. Strategic Management Journal, 25(7), 689-699.

Kirmani, A., \& Rao, A.R. (2000). No pain, no gain: A critical review of the literature on signaling unobservable product quality. Journal of Marketing, 64(2), 66-79. 
Kosová, R., Lafontaine, F., \& Perrigot, R. (2013). Organizational form and performance: Evidence from the hotel industry. Review of Economics \& Statistics, 95(4), $1303-1323$.

Kotler, P., Keller, K.L., Brady, M., Goodman, M. \& Hansen, T. (2009). Marketing Management. Essex: Pearson Education Limited.

Kozlenkova, I., Samaha, S., \& Palmatier, R. (2014). Resource-based theory in marketing. Journal of the Academy of Marketing Science, 42(1), 1-21.

Kraaijenbrink, J., Spender, J., \& Groen, A. J. (2010). The Resource-Based view: A review and assessment of its critiques. Journal of Management, 36(1), 349-372.

McCann, B. T., \& Folta, T. B. (2008). Location matters: Where we have been and where we might go in agglomeration research. Journal of Management, 34(3), 532-565.

Miller, F. (2011). Using formal and informal controls to limit opportunism: Review and classification of remedies to hold-ups. Journal of Accounting Literature, 30, 301-39.

Minkler, A. P., \& Park, T. A. (1994). Asset specificity and vertical integration in franchising. Review of Industrial Organization, 9(4), 409-423.

O'Neill, J. W., \& Mattila, A. S. (2006). Strategic hotel development and positioning. Cornell Hotel \& Restaurant Administration Quarterly, 47(2), 146-154.

O'Neill, J.W., \& Carlbäck, M. (2011). Do brands matter? A comparison of branded and independent hotels' performance during a full economic cycle. International Journal of Hospitality Management, 30(3), 515-521.

Peteraf, M. (1993). The cornerstones of competitive advantage: A resource-based view. Strategic Management Journal, 14(3), 179-191. 
Priem, R. L., \& Butler, J. E. (2001). Is the Resource-Based "view" a useful perspective for Strategic Management research? Academy of Management Review, 26(1), $22-40$

Rao, V. R., Agarwal, M. K., \& Dahlhoff, D. (2004). How is manifest branding strategy related to the intangible value of a corporation? Journal of Marketing, 68(4), 126-141.

Rumelt, R. P. (1991). How Much Does Industry Matter? Strategic Management Journal, 12(3), 167-185.

Singh, A., \& Dev, C. S. (2015). Winners and losers during the Great Recession: The positive impact of marketing expenditures. Cornell Hospitality Quarterly, 56(4), 383-396.

Schmidt, J., \& Keil, T. (2013). What makes a resource valuable? Identifying the drivers of firm-idiosyncratic resource value. Academy of Management Review, 38(2), 206-228.

Wang, H.-M.D., \& Sengupta, S. (2016). Stakeholder relationships, brand equity, firm performance: A resource-based perspective, Journal of Business Research, 69(12), $5561-5568$

Weigelt, K., \& Camerer, C. (1988). Reputation and corporate strategy: A review of recent theory and applications. Strategic Management Journal, 9(5), 443-454.

Wernerfelt, B. (1988). Umbrella branding as a signal of new product quality: an example of signaling by posting a bond. RAND Journal of Economics, 19(3), 458-466.

Williamson, O. E. (1985). The economic institutions of capitalism: firms, markets, relational contracting. New York, Free; London: Collier Macmillan. 
Table 1

Descriptives

\begin{tabular}{lcrr}
\hline Variable & N & Mean & \multicolumn{1}{c}{ SD } \\
\hline Yearly gross profit per room & 998 & $2,183.38$ & $5,362.07$ \\
Corporate brand & 998 & .04 & .18 \\
Stars & 998 & 3.12 & .75 \\
Percentage of non-branded hotels in the city & 998 & .84 & .12 \\
Brand's age & 998 & 28.89 & 16.09 \\
Vertical integration & 998 & .88 & .33 \\
Chain & 998 & .18 & .38 \\
Historical Building & 998 & .13 & .33 \\
Parking & 998 & .54 & .50 \\
24 hour room service & 998 & .13 & .34 \\
Leisure services & 998 & 3.95 & 2.84 \\
Meeting rooms & 998 & .32 & .47 \\
Family rooms & 998 & .22 & .42 \\
Accessible facilities & 998 & .15 & .36 \\
Central location & 998 & .46 & .50 \\
Hotel's uniqueness & 998 & .14 & .08 \\
Occupancy rate & 998 & 63.91 & 11.25 \\
Unemployment rate & 998 & 5.70 & 2.49 \\
\hline
\end{tabular}


Table 2

Correlations

\begin{tabular}{|c|c|c|c|c|c|c|c|c|c|c|c|c|c|c|c|c|c|}
\hline \\
\hline & 1 & 2 & 3 & 4 & 5 & 6 & 7 & 8 & 9 & 10 & 11 & 12 & 13 & 14 & 15 & 16 & 17 \\
\hline \multicolumn{18}{|l|}{ 1.Yearly gross profit per room } \\
\hline 2.Corporate brand & $.20 * *$ & & & & & & & & & & & & & & & & \\
\hline 3.Stars & .01 & $.36 * *$ & & & & & & & & & & & & & & & \\
\hline $\begin{array}{l}\text { 4.Percentage of non-branded } \\
\text { hotels in the city }\end{array}$ & $-.12 * *$ & $-.52 * *$ & $-.33 * *$ & & & & & & & & & & & & & & \\
\hline 5.Brand's age & $-.08 * *$ & $-.06 * *$ & $-.04 * *$ & $-.04 * *$ & & & & & & & & & & & & & \\
\hline 6. Vertical integration & $.15 * *$ & -.02 & $.06 *$ & $-.10 * *$ & -.01 & & & & & & & & & & & & \\
\hline 7.Chain & $.11 * *$ & $.70 * *$ & $.46 * *$ & $-.47 * *$ & $.02 * *$ & $.06 *$ & & & & & & & & & & & \\
\hline 8.Historical Building & $.13 * *$ & $.02 * *$ & $.09 * *$ & $-.03 * *$ & $-.06 * *$ & .04 & .00 & & & & & & & & & & \\
\hline 9.Parking & -.01 & $.05 * *$ & $.13 * *$ & .01 & $-.03 * *$ & .03 & $.06 * *$ & -.00 & & & & & & & & & \\
\hline 10.24 hour room service & .04 & $.08 * *$ & $.20 * *$ & $-.08 * *$ & $-.08 * *$ & .03 & $.08 * *$ & $.10 * *$ & $.10 * *$ & & & & & & & & \\
\hline 11.Leisure services & $-.07 * *$ & $.17 * *$ & $.49 * *$ & $-.12 * *$ & $.07 * *$ & .01 & $.25 * *$ & $-.04 * *$ & $.21 * *$ & $.11 * *$ & & & & & & & \\
\hline 12.Meeting rooms & $.06 *$ & $.21 * *$ & $.34 * *$ & $-.17 * *$ & $-.06 * *$ & $.05 *$ & $.22 * *$ & $.10 * *$ & $.06 * *$ & $.15 * *$ & $.23 * *$ & & & & & & \\
\hline 13.Family rooms & .03 & $.01 * *$ & $.11 * *$ & -.01 & $-.03 * *$ & -.02 & $.03 * *$ & $.02 * *$ & $.03 * *$ & $.03 * *$ & $.20 * *$ & $.32 * *$ & & & & & \\
\hline 14.Accessible facilities & .04 & $.18 * *$ & $.24 * *$ & $-.16 * *$ & $-.12 * *$ & $-.06 *$ & $.16 * *$ & $.03 * *$ & $-.02 * *$ & $.09 * *$ & $.20 * *$ & $.43 * *$ & $.24 * *$ & & & & \\
\hline 15.Central location & .00 & $-.01 *$ & $-.03 * *$ & $-.02 * *$ & $.08 * *$ & $.06 *$ & $.02 * *$ & $.06 * *$ & -.01 & $.03 * *$ & $-.10 * *$ & $-.10 * *$ & $-.09 * *$ & $-.10 * *$ & & & \\
\hline 16.Hotel's uniqueness & .02 & $.28 * *$ & $.52 * *$ & $-.23 * *$ & $.03 * *$ & .01 & $.34 * *$ & $.04 * *$ & $.22 * *$ & $.22 * *$ & $.51 * *$ & $.32 * *$ & $.18 * *$ & $.25 * *$ & $.06 * *$ & & \\
\hline 17.Occupancy rate & $.14 * *$ & $.14 * *$ & $.24 * *$ & $-.35 * *$ & $.16 * *$ & $.06 *$ & $.23 * *$ & $-.08 * *$ & $-.07 * *$ & $-.02 *$ & $.26 * *$ & $.02 * *$ & .01 & $.04 * *$ & $.04 * *$ & $.05 * *$ & \\
\hline 18.Unemployment rate & $-.08 * *$ & $.02 * *$ & $-.05 * *$ & $-.05 * *$ & $-.11 * *$ & $.10 * *$ & $-.04 * *$ & $.08 * *$ & $-.02 * *$ & $.09 * *$ & $-.13 * *$ & $.12 * *$ & $.02 * *$ & $.10 * *$ & $-.07 *$ & $.02 * *$ & $-.27 * *$ \\
\hline
\end{tabular}


Table 3

Multilevel regression analysis for yearly gross profit per room

\begin{tabular}{|c|c|c|c|c|c|c|}
\hline & Model 1 & & Model 2 & & Model 3 & \\
\hline \multirow[t]{2}{*}{ Intercept } & $3,246.62$ & & $3,086.32$ & & $3,691.76$ & \\
\hline & $(2,785.78)$ & & $(2,722.77)$ & & $(2,593.72)$ & \\
\hline \multirow[t]{2}{*}{ Stars } & -341.81 & & -336.61 & & -277.70 & \\
\hline & $(266.17)$ & & $(262.78)$ & & $(256.23)$ & \\
\hline \multirow[t]{2}{*}{ Percentage of non-branded hotels in the city } & $-3,941.76$ & & $-3,958.71$ & $*$ & -4427.12 & $*$ \\
\hline & $(2,046.09)$ & & $(1,995.70)$ & & $(1,894.71)$ & \\
\hline \multirow[t]{2}{*}{ Brand's age } & -6.04 & & 5.35 & & 5.10 & \\
\hline & $(11.43)$ & & $(11.57)$ & & $(11.21)$ & \\
\hline \multirow[t]{2}{*}{ Vertical integration } & $1,944.26$ & $* *$ & $2,167.01$ & $* *$ & $1,755.47$ & $* *$ \\
\hline & $(497.08)$ & & (494.04) & & $(492.20)$ & \\
\hline \multirow[t]{2}{*}{ Chain } & $1,153.27$ & $* *$ & 321.70 & & 242.62 & \\
\hline & $(438.70)$ & & $(470.85)$ & & $(458.94)$ & \\
\hline \multirow[t]{2}{*}{ Historical building } & $1,720.27$ & $* *$ & $1,453.71$ & $* *$ & 846.79 & \\
\hline & $(513.31)$ & & $(511.61)$ & & $(507.94)$ & \\
\hline \multirow[t]{2}{*}{ Parking } & -862.28 & $*$ & -626.76 & & -638.77 & \\
\hline & $(353.39)$ & & $(353.47)$ & & $(344.57)$ & \\
\hline \multirow[t]{2}{*}{24 hour room service } & $1,138.79$ & $*$ & $1,298.41$ & $* *$ & $1,404.96$ & $* *$ \\
\hline & (492.64) & & $(488.36)$ & & $(478.08)$ & \\
\hline \multirow[t]{2}{*}{ Leisure services } & -88.19 & & -109.26 & & -90.27 & \\
\hline & $(81.54)$ & & $(80.67)$ & & (78.91) & \\
\hline \multirow[t]{2}{*}{ Meeting rooms } & 684.51 & & 738.47 & & 903.99 & $*$ \\
\hline & $(408.71)$ & & (404.89) & & $(395.60)$ & \\
\hline \multirow[t]{2}{*}{ Family rooms } & 496.31 & & 456.57 & & 514.52 & \\
\hline & $(419.60)$ & & $(415.50)$ & & $(406.45)$ & \\
\hline \multirow[t]{2}{*}{ Accessible facilities } & 981.85 & $*$ & 806.75 & & 692.06 & \\
\hline & $(477.18)$ & & $(473.75)$ & & $(466.89)$ & \\
\hline \multirow[t]{2}{*}{ Central location } & -214.19 & & -286.05 & & -142.73 & \\
\hline & $(465.55)$ & & $(460.50)$ & & $(449.32)$ & \\
\hline \multirow{2}{*}{ Hotel's uniqueness } & $4,334.77$ & & $4,047.77$ & & $5,054.46$ & \\
\hline & $(3,125.74)$ & & $(3,093.77)$ & & $(3,024.26)$ & \\
\hline \multirow[t]{2}{*}{ Occupancy rate } & 41.94 & & 36.67 & & 32.94 & \\
\hline & $(23.68)$ & & $(23.03)$ & & $(21.72)$ & \\
\hline \multirow[t]{2}{*}{ Unemployment rate } & -202.78 & $*$ & -193.90 & $*$ & -189.21 & $*$ \\
\hline & $(98.59)$ & & $(97.94)$ & & $(94.82)$ & \\
\hline \multirow[t]{2}{*}{ Corporate brand } & & & 4,598.39 & $* *$ & $1,232.54$ & \\
\hline & & & $(1,015.58)$ & & $(18,031.46)$ & \\
\hline \multirow[t]{2}{*}{ Corporate brand x Stars } & & & & & $-6,838.55$ & $* *$ \\
\hline & & & & & $(2,343.65)$ & \\
\hline \multirow[t]{2}{*}{ Corporate brand $\mathrm{x}$ Percentage of non-branded hotels } & & & & & $1,4631.39$ & \\
\hline & & & & & $(18,236.08)$ & \\
\hline \multirow[t]{2}{*}{ Corporate brand $\mathrm{x}$ Brand's age } & & & & & 768.97 & $*$ \\
\hline & & & & & $(314.56)$ & \\
\hline Corporate Brand $\mathrm{x}$ Vertical Integration & & & & & $15,526.77$ & $* *$ \\
\hline & & & & & $(4,231.48)$ & \\
\hline Year dummies & Yes & & Yes & & Yes & \\
\hline Log likelihood & $-9,869.58$ & & $-9,859.52$ & & $-9,833.59$ & \\
\hline$n$ (hotel-year observations) & 998 & & 998 & & 998 & \\
\hline$N$ (cities) & 77 & & 77 & & 77 & \\
\hline
\end{tabular}


TABLE 4

Multilevel regression analysis for yearly gross profit per room based on number of branded competitors

\begin{tabular}{|c|c|c|c|c|c|c|c|c|}
\hline & Model 1 & & Model 2 & & Model 3 & & Model 4 & \\
\hline \multirow[t]{2}{*}{ Intercept } & 818.58 & & 737.42 & & 217.69 & & 355.95 & \\
\hline & $(1,546.25)$ & & $(1,532.11)$ & & $(1,700.14)$ & & $(1,658.18)$ & \\
\hline \multirow[t]{2}{*}{ Stars } & -352.67 & & -359.24 & & -350.79 & & -381.65 & \\
\hline & $(253.48)$ & & $(250.95)$ & & $(260.45)$ & & $(256.64)$ & \\
\hline \multirow[t]{2}{*}{ Brand's age } & 1.57 & & 1.80 & & 2.75 & & 2.66 & \\
\hline & $(11.05)$ & & $(10.94)$ & & $(11.46)$ & & $(11.27)$ & \\
\hline \multirow[t]{2}{*}{ Vertical integration } & $2,048.96$ & $* *$ & $1,844.68$ & $* *$ & $1,999.78$ & $* *$ & $1,797.87$ & $* *$ \\
\hline & $(482.09)$ & & $(479.38)$ & & $(494.95)$ & & $(489.85)$ & \\
\hline \multirow[t]{2}{*}{ Chain } & 378.50 & & 348.47 & & 455.34 & & 414.18 & \\
\hline & $(459.79)$ & & $(455.27)$ & & $(467.50)$ & & $(461.63)$ & \\
\hline \multirow[t]{2}{*}{ Historical building } & $1,307.81$ & $* *$ & $1,163.08$ & $*$ & $1,308.81$ & $*$ & $1,151.90$ & $*$ \\
\hline & $(502.99)$ & & $(499.02)$ & & $(511.66)$ & & $(506.16)$ & \\
\hline \multirow[t]{2}{*}{ Parking } & -593.45 & & -587.15 & & -603.49 & & -589.15 & \\
\hline & $(347.18)$ & & (343.67) & & (351.64) & & $(347.15)$ & \\
\hline \multirow[t]{2}{*}{24 hour room service } & $1,251.17$ & $* *$ & $1,143.05$ & $*$ & $1,305.41$ & $* *$ & $1,176.94$ & $*$ \\
\hline & $(479.44)$ & & $(475.18)$ & & $(485.01)$ & & $(479.51)$ & \\
\hline \multirow[t]{2}{*}{ Leisure services } & -100.55 & & -74.81 & & -138.51 & & -107.48 & \\
\hline & $(78.81)$ & & $(78.23)$ & & $(79.42)$ & & $(78.59)$ & \\
\hline \multirow[t]{2}{*}{ Meeting rooms } & 891.41 & $*$ & 917.25 & $*$ & 855.39 & $*$ & 906.81 & $*$ \\
\hline & $(396.21)$ & & $(392.28)$ & & $(400.54)$ & & $(395.71)$ & \\
\hline \multirow[t]{2}{*}{ Family rooms } & 430.83 & & 518.36 & & 446.63 & & 546.19 & \\
\hline & $(409.63)$ & & $(405.92)$ & & $(412.46)$ & & $(408.15)$ & \\
\hline \multirow[t]{2}{*}{ Accessible facilities } & 840.27 & & 955.38 & $*$ & 846.33 & & 992.11 & $*$ \\
\hline & $(464.86)$ & & $(460.85)$ & & $(471.50)$ & & $(466.35)$ & \\
\hline \multirow[t]{2}{*}{ Central location } & -312.69 & & -155.77 & & -308.58 & & -163.67 & \\
\hline & $(450.49)$ & & $(447.20)$ & & $(456.60)$ & & $(451.91)$ & \\
\hline \multirow[t]{2}{*}{ Hotel's uniqueness } & $3,707.30$ & & 4450.37 & & $4,721.29$ & & $5,620.22$ & \\
\hline & $(3,041.13)$ & & $(3,014.72)$ & & $(3,084.12)$ & & $(3,049.31)$ & \\
\hline \multirow[t]{2}{*}{ Occupancy rate } & 8.66 & & 9.96 & & 22.03 & & 18.74 & \\
\hline & (19.80) & & $(19.63)$ & & $(22.82)$ & & $(22.10)$ & \\
\hline \multirow[t]{2}{*}{ Unemployment rate } & -149.98 & & -139.37 & & -151.77 & & -133.44 & \\
\hline & $(88.35)$ & & $(87.71)$ & & $(96.72)$ & & $(94.87)$ & \\
\hline \multirow{2}{*}{ Corporate brand } & $4,232.76$ & $* *$ & 47.89 & & $4,428.44$ & $* *$ & $-1,207.34$ & \\
\hline & $(997.79)$ & & $(1,348.90)$ & & $(1,011.82)$ & & $(1,528.49)$ & \\
\hline \multirow{2}{*}{$\begin{array}{l}\text { Number of branded hotels in the } \\
\text { city }\end{array}$} & 70.35 & $* *$ & 62.07 & $* *$ & & & & \\
\hline & (11.68) & & $(11.75)$ & & & & & \\
\hline \multirow{2}{*}{$\begin{array}{l}\text { Corporate brand } x \text { Number of } \\
\text { branded hotels in the city }\end{array}$} & & & 98.81 & $* *$ & & & & \\
\hline & & & $(21.68)$ & & & & & \\
\hline \multirow{2}{*}{$\begin{array}{l}\text { Number of branded hotels in a } \\
\text { radius of } 2 \mathrm{Km} \text {. }\end{array}$} & & & & & 97.34 & $* *$ & 94.55 & $* *$ \\
\hline & & & & & $(27.18)$ & & $(26.13)$ & \\
\hline \multirow{2}{*}{$\begin{array}{l}\text { Corporate brand } x \text { Number of } \\
\text { branded hotels in a radius of } 2 \mathrm{Km} \text {. }\end{array}$} & & & & & & & 301.35 & $* *$ \\
\hline & & & & & & & $(61.74)$ & \\
\hline Year dummies & Yes & & Yes & & Yes & & Yes & \\
\hline Log likelihood & $9,851.04$ & & $9,840.76$ & & $9,855.57$ & & $9,843.86$ & \\
\hline n (hotel-year observations) & 998 & & 998 & & 998 & & 998 & \\
\hline$N$ (cities) & 77 & & 77 & & 77 & & 77 & \\
\hline
\end{tabular}


TABLE 5

Multilevel regression analysis for yearly gross profit per room based on number of branded and number of non-branded competitors

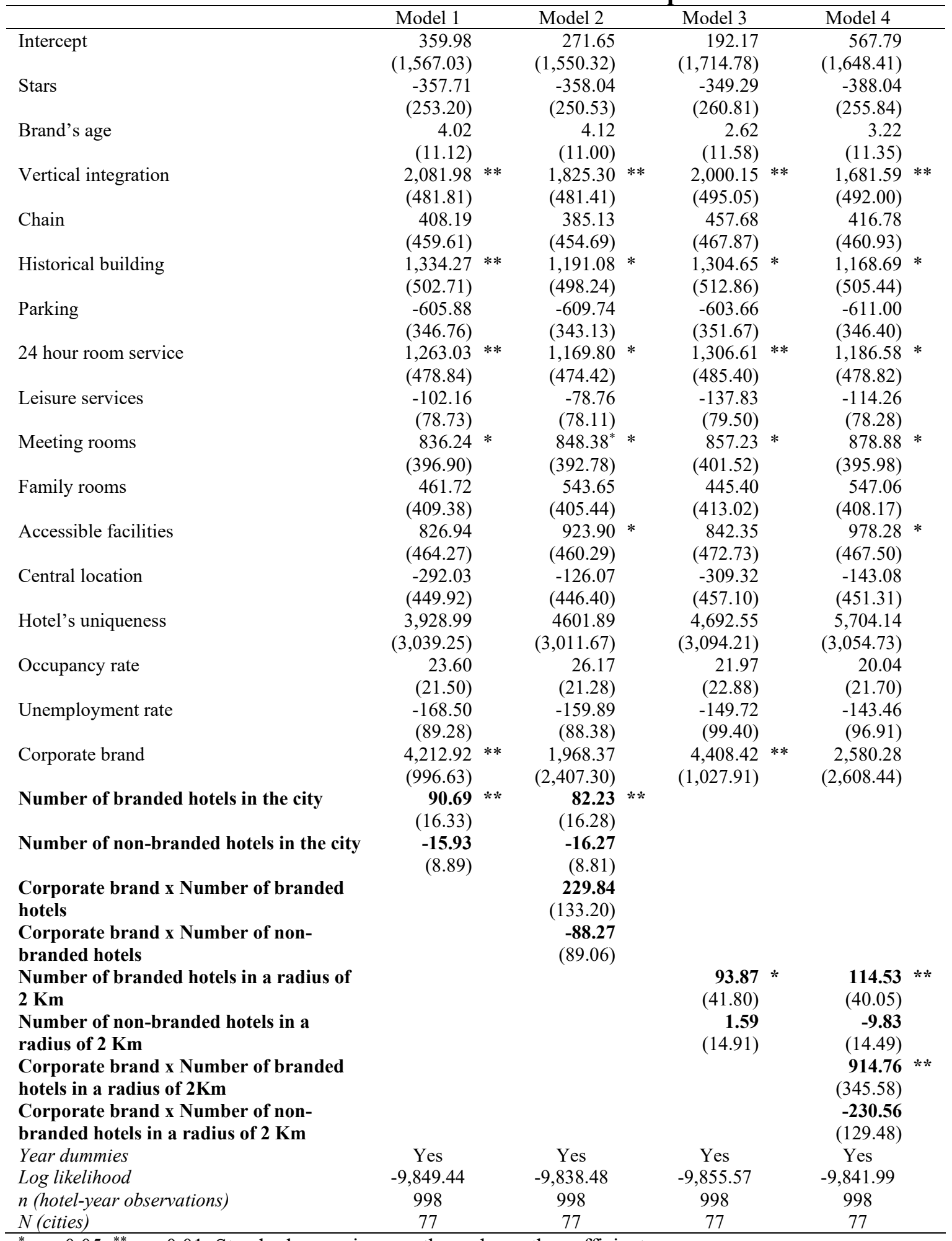

${ }^{*} p<0.05,{ }^{* *} p<0.01$; Standard errors in parentheses beneath coefficients 